\title{
Self-employed immigrants and their employees: evidence from Swedish employer-employee data
}

\author{
Mats Hammarstedt $\mathbb{C}^{1} \cdot$ Chizheng Miao $^{1}$
}

Received: 7 September 2018 / Accepted: 19 March 2019 / Published online: 30 March 2019

(c) The Author(s) 2019; This article is published with open access at Springerlink.com

\begin{abstract}
We present a study of the employees of self-employed immigrants with unincorporated firms in Sweden using matched employer-employee data from 2014. Non-European immigrants are more likely than natives to have employees in their firms. Furthermore, immigrants, especially non-European immigrants, are more likely than natives to employ immigrants in their firms, and non-European immigrants are most likely to employ recently arrived non-European immigrants with low education in their firms. Males are more likely than females to have employees in their firms, but self-employed females are more likely than selfemployed males to have female employees. This is the case for all immigrant groups as well as for natives. We conclude that self-employed immigrants play a role in the labour market integration process since they create employment opportunities for immigrant groups that have difficulty entering the labour market.
\end{abstract}

Keywords Self-employment $\cdot$ Immigrants $\cdot$ Employment $\cdot$ Employees $\cdot$ Sweden

JEL Codes J61 $\cdot \mathrm{L} 26 \cdot \mathrm{F} 22 \cdot \mathrm{J} 21$

This paper is part of a project titled Self-employment among female Middle Eastern immigrants: Determinants, obstacles and outcomes, financed by Jan Wallanders and Tom Hedelius Stiftelse. The research grant is gratefully acknowledged. The authors are also grateful for the comments provided during the workshop "Immigration, ethnic enclaves and labour market outcomes" in Jönköping in 2018, the LNUC workshop in Båstad in 2018, the ESPE conference in Antwerp in 2018, and the Swedish National Conference on Economics in Växjö in 2018.

Mats Hammarstedt

mats.hammarstedt@lnu.se

1 Linnaeus University Centre for Discrimination and Integration Studies, Linnaeus University, Växjö SE-351 95, Sweden 


\section{Introduction}

The self-employment sector may play an important role in the integration of foreignborn individuals in the labour market. Self-employment may be a route into the labour market for individuals who would like to make a living in a new country; moreover, immigrants who start their own businesses may also offer employment opportunities for other immigrants.

Research has shown there are differences in self-employment rates between the foreign-born population and natives in several OECD countries. ${ }^{1}$ Much research has been devoted to explanations behind these observed differences, and scholars have attributed these differences to such factors as discrimination in wage-employment, traditions from the home country, the existence of ethnic enclaves, and family traditions. $^{2}$

This paper presents new knowledge regarding immigrant self-employment by focusing on self-employed immigrants and their employees in Sweden. Regarding employees of self-employed individuals with an immigrant background, Henley (2005) shows that in the UK, self-employed individuals from ethnic minority groups are less likely to hire employees than self-employed natives are, while Clark et al. (2017) show that self-employed immigrants with a recent year of arrival are less likely to have employees than self-employed immigrants who arrived earlier.

In the US, Fairlie and Miranda (2017) show that self-employed individuals from certain ethnic groups, such as Asians and Hispanics, have a higher probability of hiring employees in their firms than natives are. Furthermore, Fairlie and Miranda (2017) have found that female-owned businesses are less likely to hire employees than male-owned businesses are.

Furthermore, the literature has shown that a common culture between managers and workers may facilitate communication and increase productivity. ${ }^{3}$ Empirical studies have focused on the extent to which managers hire workers with a background similar to their own, and workers to whom they are socially connected. In the US, Bandiera et al. (2009) and Giuliano et al. (2009) have documented biases in hiring and that managers' origin matters for recruitment patterns. Åslund et al. (2014) have reported similar results in Sweden.

Against this background, we have different reasons for conducting a study that focuses on the employees of self-employed immigrants in Sweden. First, integration problems encountered by non-European immigrants in entering the Swedish labour market are well documented. ${ }^{4}$ Furthermore, high rates of self-employment for certain

\footnotetext{
1 For studies from the US, see e.g., Borjas (1986); Yuengert (1995); Fairlie and Meyer (1996); Fairlie (1999); Hout and Rosen (2000); Fairlie and Robb (2007) and Robb and Fairlie (2009). For a study from Australia, see Le (2000). For studies from European countries, see e.g., Clark and Drinkwater (2000) and Clark et al. (2017) for the UK; Constant and Zimmermann (2006) for Germany; and Hammarstedt (2001, 2004, 2006) for Sweden.

2 Determinants behind the self-employment decision among immigrants in different countries have been tested by Borjas (1986); Yuengert (1995); Fairlie and Meyer (1996); Clark and Drinkwater (2000, 2002); Hammarstedt and Shukur (2009); Andersson and Hammarstedt (2010, 2011, 2015), and Aldén and Hammarstedt (2016).
}

3 See Lazear (1999), Den Butter et al. (2004)

4 See e.g., Aldén and Hammarstedt (2015). 
groups of non-European immigrants have also been documented. ${ }^{5}$ Accordingly, the policy relevance of studying the employees of self-employed immigrants is evident. If self-employed immigrants employ other immigrants, especially those who have problems entering the labour market, they will play an important role in the integration process of immigrants in the labour market.

In a previous study Andersson and Wadensjö (2009) have illustrated that both self-employed natives and self-employed immigrants in Sweden are likely to employ workers of their own nationality in their firms. ${ }^{6}$ We contribute knowledge to this field since we are focusing on the extent to which self-employed immigrants from different regions employ certain groups of immigrants, such as immigrants from their own group, recently arrived immigrants and immigrants with different educational attainments in their firms. We also explore the extent to which there are differences between self-employed male and female immigrants and between self-employed immigrants with different times of arrival in Sweden regarding these issues. Accordingly, our study highlights several dimensions of immigrant self-employment and the role self-employed immigrants play in the process of integrating immigrants into the labour market.

Our study is supported by unique matched employer-employee data obtained from Statistics Sweden for the year 2014. We focus on unincorporated firms with single owners. ${ }^{7}$ Because those firms are usually small and typically have an owner-manager structure, it makes the owners more likely to be involved in the recruitment process than owners of incorporated firms. Our results reveal that non-European immigrants are more likely to have employees in their firms than natives and European immigrants are. Furthermore, immigrants are more likely to have immigrants as employees in the firms than natives are. Non-European immigrants are most likely to hire recently arrived non-European immigrants with low education as employees. Males are more likely to have employees in their firms than females are, but selfemployed females are more likely to employ other females. This is the case for all immigrant groups as well as for natives. Self-employment among immigrants may therefore play an important role in the integration process, since being employed by an immigrant may be a route into the Swedish labour market for newly arrived immigrants.

The remainder of the paper is organised as follows. The immigrant population in Sweden is described in Section 2. Section 3 contains the data; Section 4 explains the empirical strategy. Section 5 offers some descriptive statistics, and Section 6 presents the results. Finally, Section 7 concludes.

\footnotetext{
5 See e.g., Aldén and Hammarstedt (2017).

6 Andersson-Joona and Wadensjö (2012) studied the earnings and employment effect of being employed by a co-national.

7 Incorporated firms and firms with more than one owner are excluded from the analysis.
} 


\section{The immigrant population in Sweden}

Sweden has a long history of immigration. The characteristics of this immigration have changed over the years. ${ }^{8}$ After World War II, immigration to Sweden consisted primarily of refugees from Eastern Europe. However, in the wake of industrial and economic expansion during the 1950s, labour force migration reached significant proportions, peaking during the 1950s and 1960s, with the influx of immigrants coming predominantly from Sweden's neighbours (e.g., Finland) and from countries in Western and Southern Europe (e.g., Italy, Greece, West Germany, Yugoslavia).

Labour force migration tapered off during the late 1960s. Since then, immigration to Sweden has consisted primarily of refugee immigrants and 'tied movers' or relatives of already admitted immigrants. In the 1970s, refugee migration from Latin America increased, while during the 1980s, many refugees came from Africa and the Middle East.

Migration from Europe increased temporarily again during the early 1990s. This involved refugees fleeing the civil war in former Yugoslavia. Since the mid-1990s, most of the immigrants to Sweden have been refugees from countries in and around the Middle East and Africa. During the 1990s and since 2000, refugees from Iraq have immigrated to Sweden. In the 2000s, people from Iraq, Somalia, Syria and Afghanistan have accounted for most of the immigration to Sweden, adding significantly to the numbers of Sweden's foreign-born population.

As of 2019, almost 20 per cent of Sweden's total population has been born abroad. The change from labour force migration to refugee migration has transformed the composition of the country's immigrant population. During recent decades, the share of immigrants born outside Europe has grown markedly, and in 2019, around 55 per cent of the foreign-born population originated from countries outside Europe, with Syria, Iraq, Iran and Somalia being the dominant countries. The dominant European countries from which immigrants have come to Sweden are Finland, Poland and the former Yugoslavia. ${ }^{9}$

\section{Data}

We use data from the Longitudinal integration database for health insurance and labour market studies (LISA) at Statistics Sweden for the year 2014. This database contains information about all individuals 16 years of age or older who reside in Sweden.

In order to define who is self-employed we employ Statistics Sweden's definition of self-employment as a person registered as self-employed in November 2014. Furthermore, we restrict our analysis to individuals self-employed in unincorporated firms. Only individuals registered as self-employed and who are single owners of their firms are included in the study.

We classify immigrants into eight groups, depending on where they were born: The groups are: immigrants born in the Nordic countries (excluding Sweden),

\footnotetext{
${ }^{8}$ Boguslaw (2012) presents a detailed description and discussion about Sweden's immigration history.

9 See Statistics Sweden, www.scb.se. 
Western Europe, Eastern Europe, Southern Europe, the Middle East, Asia, Africa and Latin America. ${ }^{10}$ Moreover, we have divided the immigrant groups according to their year of immigration. Four different groups are used: immigrants who arrived before 1990, between 1990 and 1999, between 2000 and 2009 and those who arrived after 2009. The comparison group is made up of individuals born in Sweden.

The data enable us to link employers and employees to each other, which is made possible by the fact that each firm and each employee have a unique identification number. We have information about the firm in which an individual was employed in November 2014. We are thus able to trace everyone employed by someone who is self-employed, which enables us to investigate who is being hired by self-employed immigrants and natives.

We first create a variable that measures whether a person was self-employed and had at least one employee or not. The data provides information about whether the firms had employees and about the age, marital status, gender, region of birth, time of arrival in Sweden and the educational attainment of the employees. Using this information, we created a set of variables that measures whether a self-employed individual had at least one female employee, at least one immigrant employee, at least one male immigrant employee, at least one female immigrant employee, at least one non-European immigrant employee, at least one non-European male immigrant employee, at least one non-European female immigrant employee, at least one recently arrived non-European immigrant employee (immigrated after 2009) and at least one recently arrived non-European immigrant employee with low educational attainment (nine years of compulsory school or less). ${ }^{11}$

In total, our sample consists of 72803 self-employed men, of which 18232 are immigrants and 54571 are natives, and of 46010 self-employed women, of which 10 382 are immigrants and 35628 are natives.

\section{Empirical strategy}

In order to answer the question of whether self-employed immigrants employ other immigrants with certain characteristics in their firms, we use two different model specifications. First, we investigate whether there are differences between different groups of immigrants and natives in the probability of having employees in their firms. We estimate the following linear probability model for self-employed males and females separately:

$$
\mathrm{Empl}_{i}=\alpha+\beta_{j} \sum_{j=1}^{8} i m m g_{i j}+X_{i}^{\prime} \gamma+Z_{m}^{\prime} \delta+L A_{l}+\epsilon_{i}
$$

where $i, j, m$ and $l$ indicate the individual, immigrant group, firm and local labour market, respectively. The binary dependent variable $E m p l_{i}$ takes a value of 1 if the self-employed individual has at least one employee in the firm, and zero otherwise. Our variable of interest is $\beta_{j}$, which is the estimated coefficient associated with different groups of immigrants. The reference group is made up of self-employed

\footnotetext{
$\overline{{ }^{10}}$ The countries in each region are presented in Table 9 in the Appendix.

11 All variables are presented in Table 10 in the Appendix.
} 
natives. $X_{i}$ is a vector of socio-economic variables consisting of age, marital status, education and the number of dependent children. $Z_{m}$ is a set of dummy variables for the business branches in which a firm is active. $L A_{l}$ is a set of dummy variables that indicate the residential local labour market. By controlling local labour market fixed effects, we compare the hiring behaviour of self-employed people within the same local labour market. Finally, $\varepsilon_{i}$ is the error term.

Furthermore, we want to analyse the extent to which self-employed immigrants hire certain groups of immigrants as their employees. To analyse this, we restrict the sample to self-employed individuals with employees. We specify the following model separately for self-employed males and females who have employees:

$$
\text { EE_type }_{i}=\alpha+\beta_{j} \sum_{j=1}^{8} \text { immg }_{i j}+X_{i}^{\prime} \gamma+\theta \text { firm size } e_{m}+Z_{m}^{\prime} \delta+L A_{l}+\epsilon_{i}
$$

The dependent variable $E E \_t y p e_{i}$ indicates different binary outcome variables that relate to the likelihood of having any immigrant and gender-specific employees in the firm. Again, the variables $i m m g_{i j}$ are the eight immigrant group dummies. In the regression, the reference group is self-employed natives with employees. Compared with Specification (1), among the firm characteristics, we further control for firm size in the regression specification (2), measured as the number of employees in the firm. ${ }^{12}$

To investigate the recruitment behaviour of self-employed immigrants across different cohorts, we use the same model specification of (1) and (2) but replace the eight immigrant group dummies by the four immigrant cohort dummies.

\section{Descriptive statistics}

\subsection{Background characteristics of self-employed immigrants}

Tables 1 and 2 present descriptive statistics for all self-employed immigrants and natives and for self-employed immigrants and natives with employees in their firms. Table 1 reveals that there are small age differences between the self-employed immigrants and self-employed natives, which averages around 45 years for most of the groups. The one exception is immigrants from the Nordic countries, for which the average age is somewhat higher. Furthermore, non-European females are, on average, somewhat younger-about 42 years old.

The descriptive statistics show that the share of low educated individuals who are self-employed is higher among immigrants from countries in the Middle East or other Asian countries than among other immigrants and natives. Around 34 per cent of self-employed males originating from Middle Eastern countries had nine years of compulsory schooling or less, while more than 38 per cent of self-employed females originating from Asian countries were classified with that educational attainment. Among self-employed native males, around 16 per cent had nine years of compulsory schooling or less, while this share amounted to around 9 per cent among native females.

\footnotetext{
12 All variables are presented in Table 10 in the Appendix.
} 


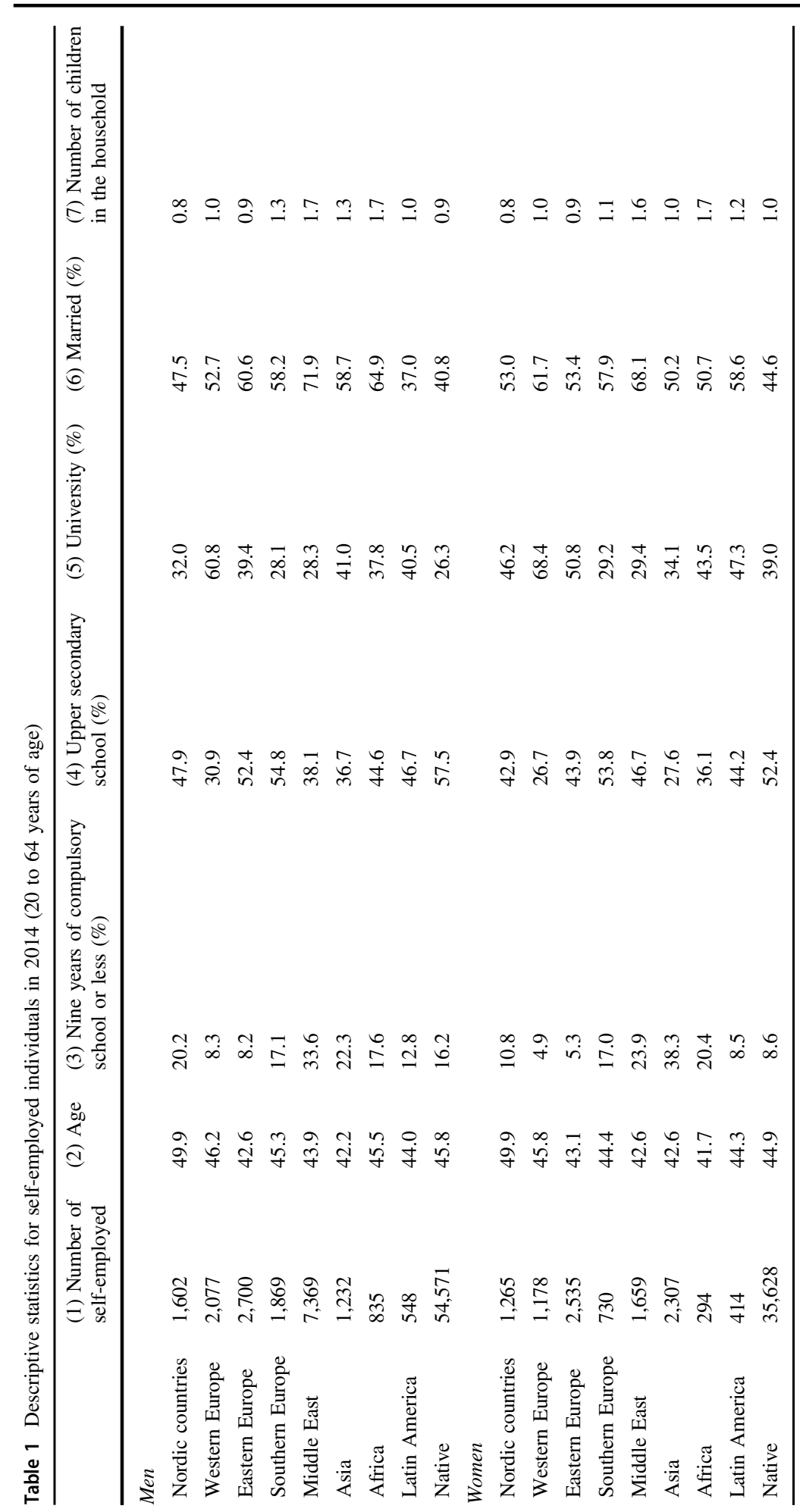




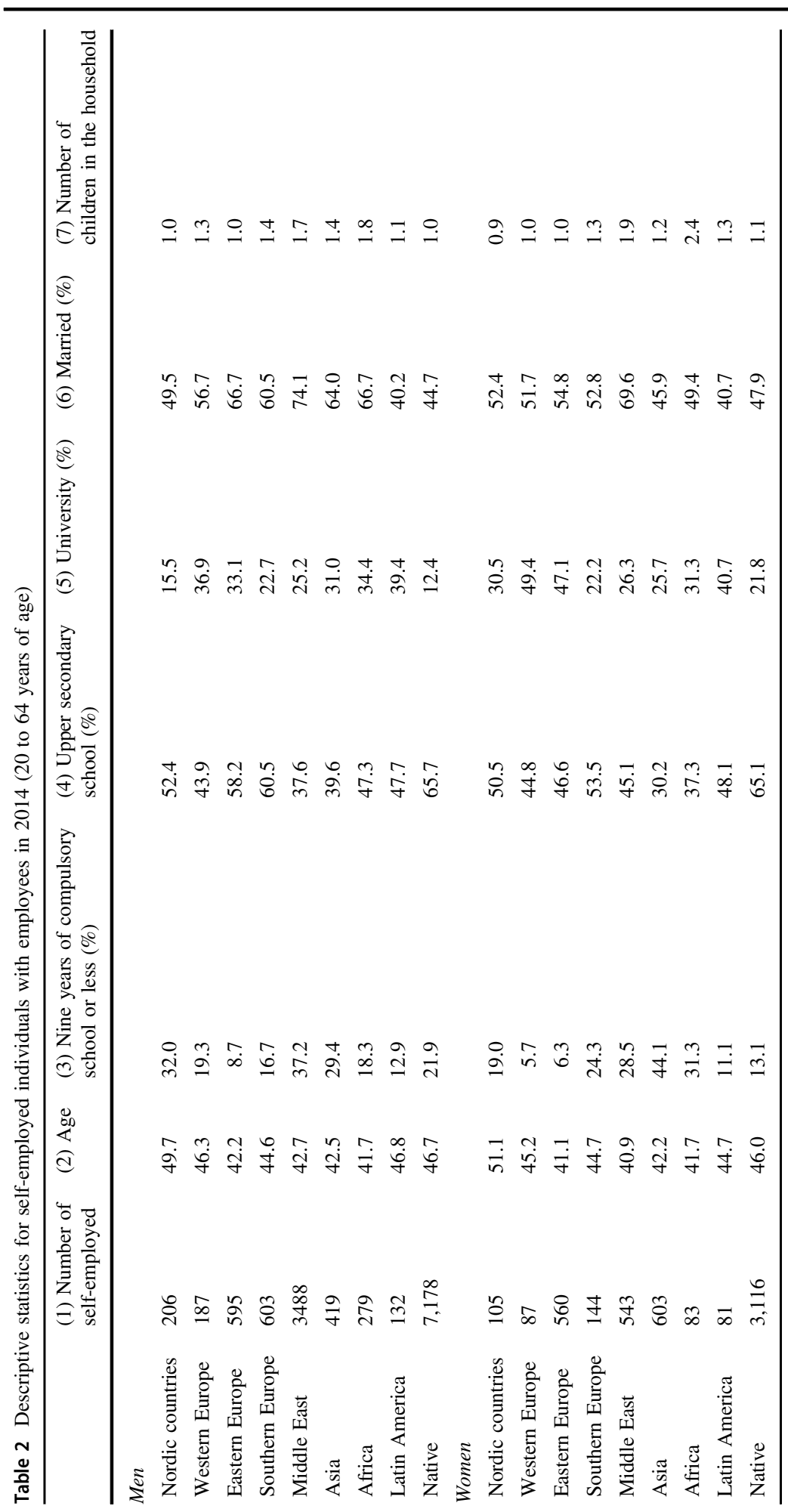


The share of self-employed individuals with a university education is high among immigrants from Western Europe-around 61 and 68 per cent for males and females, respectively. It is worth noting that the share of self-employed individuals with a university education is higher than among natives in most of the immigrant groups.

Turning to the family context, we find that male self-employed immigrants originating from countries in the Middle East, other Asian countries or Africa are more likely to be married and have children in the household than other immigrants and natives. Our study found that around 72 per cent of self-employed males originating from the Middle East were married. Among male immigrants from other Asian countries and Africa this share amounted to around 59 and 65 per cent, respectively. Among self-employed females from the Middle East, around 68 per cent were married. Several studies have documented high self-employment rates among Middle Eastern immigrants in Sweden. ${ }^{13}$ These results are in line with a study by Borjas (1986), who argues that the family situation is important for immigrants deciding to opt for self-employment.

Are self-employed immigrants with employees different from self-employed immigrants without employees in their firms in observable background characteristics? To answer this question, we turn our attention to Table 2. One striking difference emerges in terms of educational attainment. The share of individuals who have a university education is considerably lower among self-employed individuals with employees than among the total sample of self-employed individuals. Thus, self-employed individuals with higher educational qualifications are less likely to have employees in their firms than self-employed individuals with lower educational status. This is the case for all immigrant groups as well as for natives.

It is also worth noting that the share of individuals who are married is higher among self-employed males with employees than among the total sample of selfemployed males. Among self-employed males originating from the Middle East who had employees, around 74 per cent were married. Among native self-employed males with employees, the share that was married was around 45 per cent.

The number of children in the household is relatively high among self-employed females originating from the Middle East, other Asian countries or Africa, who have employees in their firms. Again, this underlines the importance of the family situation for immigrants' likelihood of becoming successful self-employers. Family members are a reliable source of labour and it is highly plausible that children are often hired as employees in small immigrant-owned firms.

Thus, we can conclude that the share of self-employed individuals with low educational attainment is relatively high among immigrants from the Middle East and from other Asian countries. Furthermore, the family situation seem to be of importance for the self-employment decision among immigrants from these regions.

\subsection{Employees of self-employed immigrants}

Table 3 presents the share of self-employed individuals who have employees in their firms, and the share of employees with different characteristics in firms owned by different groups of immigrants and natives. The share of self-employed individuals

$\overline{13}$ See e.g., Hammarstedt $(2001,2006)$ and Aldén and Hammarstedt $(2017)$. 


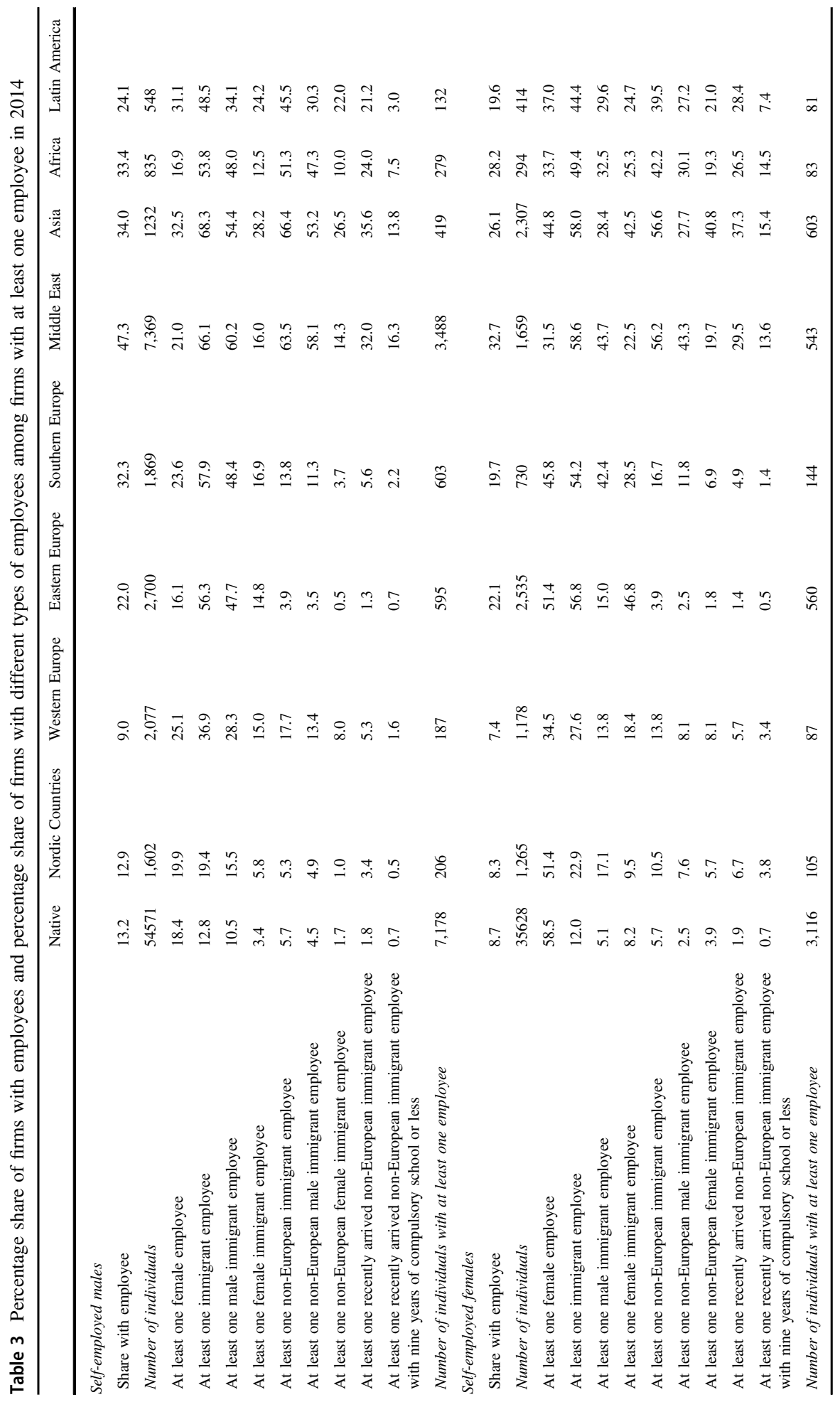


with at least one employee varies substantially across different groups. More than 47 per cent of self-employed males originating from the Middle East have at least one employee. This share is relatively high among other non-European groups. Among males from countries in Asia, the share of self-employed with at least one employee amounts to around 34 per cent. The share among native men, and among men from the Nordic countries and Western Europe is much lower-around 10 per cent.

The table also reveals that self-employed immigrant males are more likely than natives to employ other immigrants in their firms. This is especially the case for nonEuropean immigrants. Around 66 per cent of self-employed immigrants from the Middle East and around 68 per cent of self-employed individuals from Asia who have employees have at least one immigrant employee. The corresponding share among male natives is less than 13 per cent.

Large differences between the groups also appear when we study the propensity for having non-European immigrants as employees. About 63 per cent of selfemployed males originating from the Middle East with employees had at least one non-European employee. Furthermore, about 58 per cent of firms who had employees and were owned by a male from the Middle East had at least one male non-European immigrant among their employees, while only about 14 per cent of such firms had at least one female non-European immigrant among their employees. Less than 6 per cent of native males with employees had at least one non-European immigrant employee.

Self-employed immigrant males from non-European countries also have a high propensity for employing non-European immigrants with low educational attainment and a recent year of arrival. Table 3 reveals that more than 30 per cent of firms with employees that were owned by males from the Middle East or Asia had at least one recently arrived non-European employee. Among self-employed native males with employees, this share amounted to less than 2 per cent. Finally, self-employed males from the Middle East or other Asian countries were also more likely than others to employ recently arrived non-European immigrants with a low education.

Males are more likely than females to have employees in their firms. This is the case for all immigrant groups as well as for natives. However, it is worth noting that self-employed females are more likely than males to have female employees. This is also the case for all immigrant groups as well as for natives. Self-employed females from non-European countries are more likely than female natives and female European immigrants to have employees in their firms.

Self-employed females from non-European countries are also more likely than other females to have non-Europeans as their employees. Around 56 per cent of selfemployed females originating from the Middle East or other Asian countries with employees in their firms had at least one non-European employee. The corresponding share among self-employed female natives amounted to less than 6 per cent.

The share of self-employed females who had at least one non-European immigrant employee with a recent year of arrival amounted to around 30 per cent among selfemployed females who had employees and originated from countries in the Middle East. For females originating from other Asian countries the share was even higher-over 37 per cent. The corresponding share among self-employed female natives with employees amounted to less than 2 per cent. Furthermore, self-employed females with a non-European background were much more likely to employ low 
educated non-European immigrants with a recent year of arrival than self-employed female natives and self-employed females originating from European countries.

To sum up, males are more likely than females to have employees in their firms, but self-employed females are more likely than self-employed males to have female employees. Furthermore, a clear pattern emerges since non-European immigrants are more likely than natives and immigrants from European countries to have employees in their firms. They are also more likely than natives and immigrants from European countries to employ immigrants, and also recently arrived immigrants with low education, in their firms.

\section{Results}

\subsection{The propensity of different immigrant groups for having employees}

In this section we study the propensity of self-employed immigrants and natives for having employees, and the extent to which self-employed immigrants and natives employ immigrants from different groups in their firms. All estimations are conducted with the help of a linear probability model and presented separately for males and females.

Table 4 presents the estimation results for self-employed males. In the first two columns, we investigate the probability of hiring at least one employee in the firm. In Column 1, estimated without controls, we find that self-employed immigrants, with the exception of those from Nordic and Western European countries, are more likely to have employees in their firms than self-employed natives are.

In Column 2, after controlling for different characteristics, the estimated coefficients in most cases become smaller but remain positive and statistically significant. Thus, male self-employed immigrants are more likely than self-employed native males to have employees in their firms. The difference in the propensity for having employees between males originating from the Middle East and native males is around 20 percentage points.

The results from the full estimations are presented in Table 11 in the Appendix. Regarding the results for individual and firm characteristics, we find that being married and the number of children at home are positively correlated with the probability of employing others. We find that self-employed individuals with a university or upper secondary school education are less likely to hire employees than self-employed individuals with nine years of compulsory schooling or a shorter education.

In Column 3 we estimate the propensity for having a female employee in the firm. In this regard, differences between different groups of immigrants and natives are found. While self-employed males originating from the Middle East or Western Europe are less likely to have a female employee in the firm than natives are, selfemployed males from Asia and Latin America are more likely to have a female employee in the firm than natives are.

Column 4 to 9 presents the results from the estimations of having immigrants and non-European immigrants as employees in firms. The results are in line with what was found in Table 3. Self-employed male immigrants are more likely to employ 


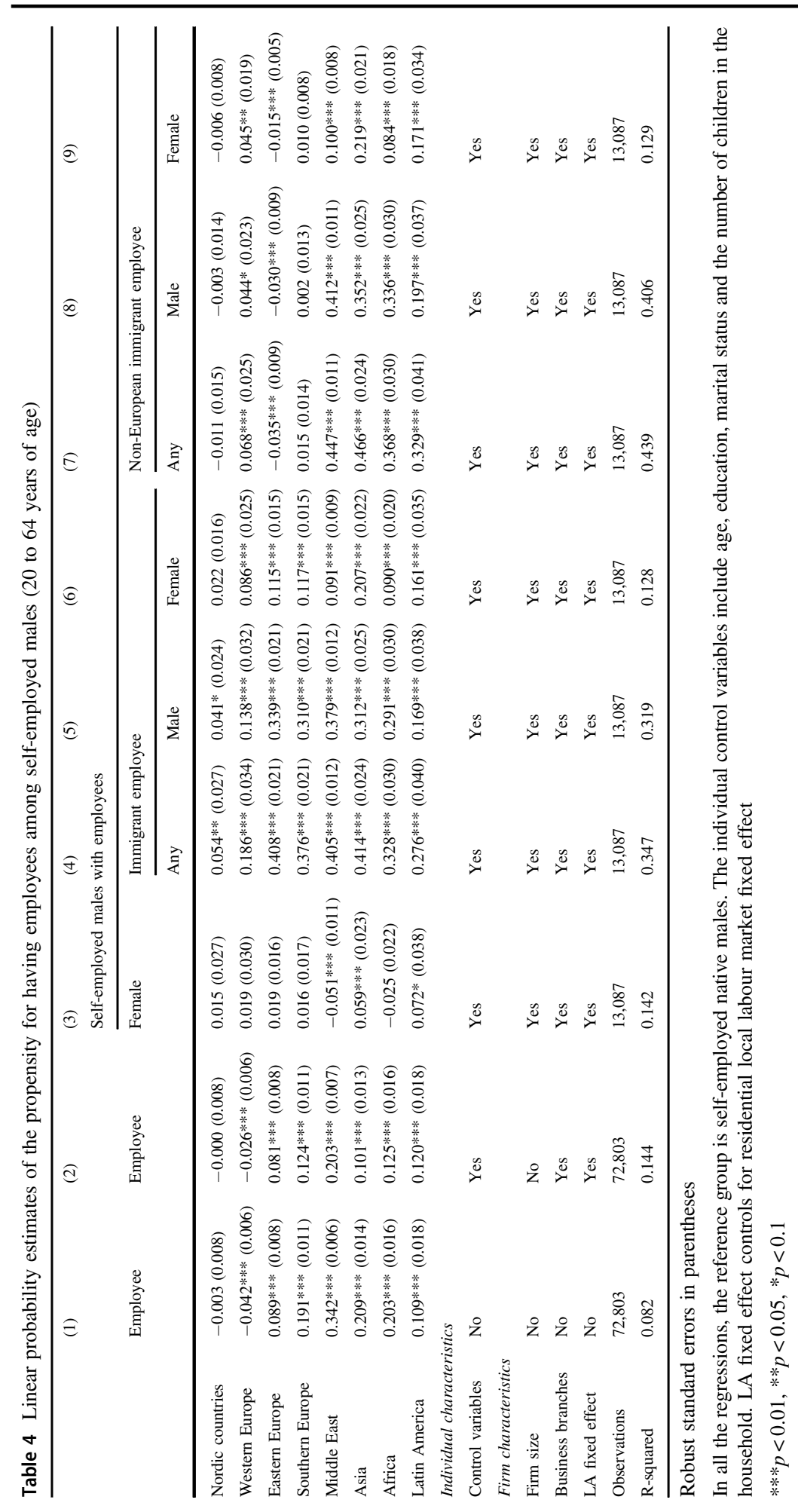


immigrants in their firms than male natives are. Furthermore, self-employed males originating from non-European countries are more likely to employ non-European immigrants in their firms than other self-employed individuals are. After controlling for individual and firm characteristics, the difference between self-employed males originating from the Middle East or other Asian countries and self-employed male natives with a propensity for having a non-European immigrant employee is about 45 percentage points.

Turning to females in Table 5, we find that self-employed females from Eastern Europe, Southern Europe and non-European countries are more likely than natives to have employees in their firms. After controlling for different characteristics in Column 2, the difference between females originating from the Middle East and native females regarding the propensity for having employees is 15 percentage points. ${ }^{14}$

Furthermore, as shown in Column 3, self-employed female immigrants are less likely to have female employees in their firms than self-employed female natives are. The difference between self-employed females originating from countries in the Middle East and self-employed female natives who have this propensity is around 24 percentage points.

Just as for males, the results in Column 4 to Column 9 are in line with what was presented in Table 3. Self-employed female immigrants are more likely to have immigrants as employees in their firms than self-employed female natives are. Column 7 shows that the propensity for having non-European immigrants as employees is about 45 percentage points higher for self-employed females originating from the Middle East or other Asian countries than it is for self-employed native females.

To sum up, we observe that self-employed non-European immigrants are more likely to have employees in the firm than self-employed natives. Moreover, selfemployed immigrants from non-European countries have a higher probability of hiring non-European immigrant employees in their firms than self-employed natives. In terms of the gender of the employees, self-employed men and women from the Middle East are less likely to hire female employees than natives are, but are more likely to hire a female employee with an immigrant background than self-employed natives are. A plausible reason that self-employed immigrants hire immigrants at such a high rate is that employers may prefer to hire employees from their own country or group. ${ }^{15}$ Another possible explanation may relate to firm's profit maximization. A similar culture between managers and workers may result in increased productivity. ${ }^{16}$

\subsection{The propensity for having employees for different immigrant cohorts}

It is reasonable to believe that time spent in a new country relates not only to the immigrant's decision to become self-employed, but also to the decision about whether or not to have employees. Tables 6 and 7 repeat the exercise from Tables 4

\footnotetext{
${ }^{14}$ The full estimates are presented in Table 12 in the Appendix.

${ }^{15}$ See Becker (1957).

${ }^{16}$ See Lazear (1999); Den Butter et al. (2004).
} 


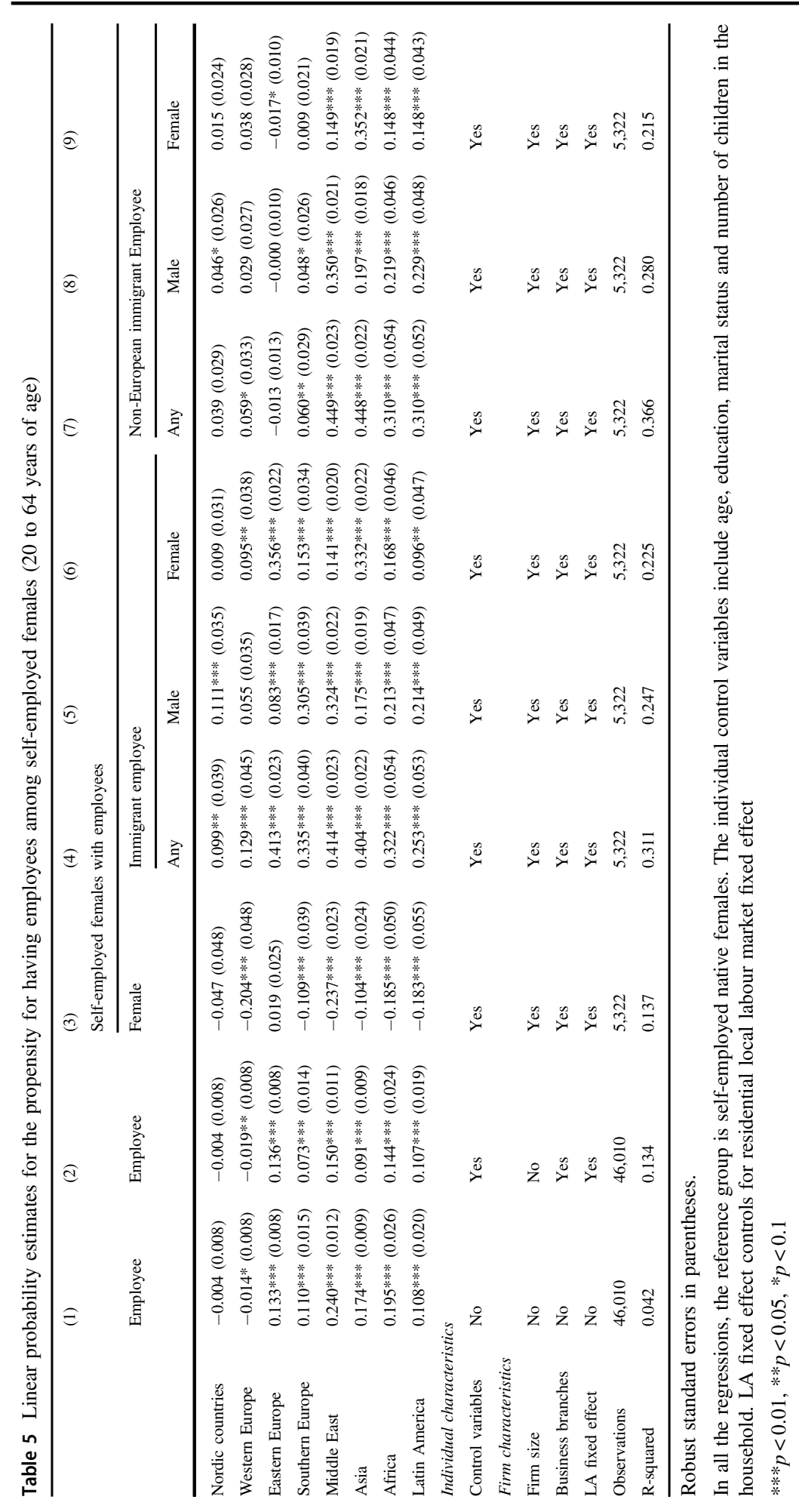




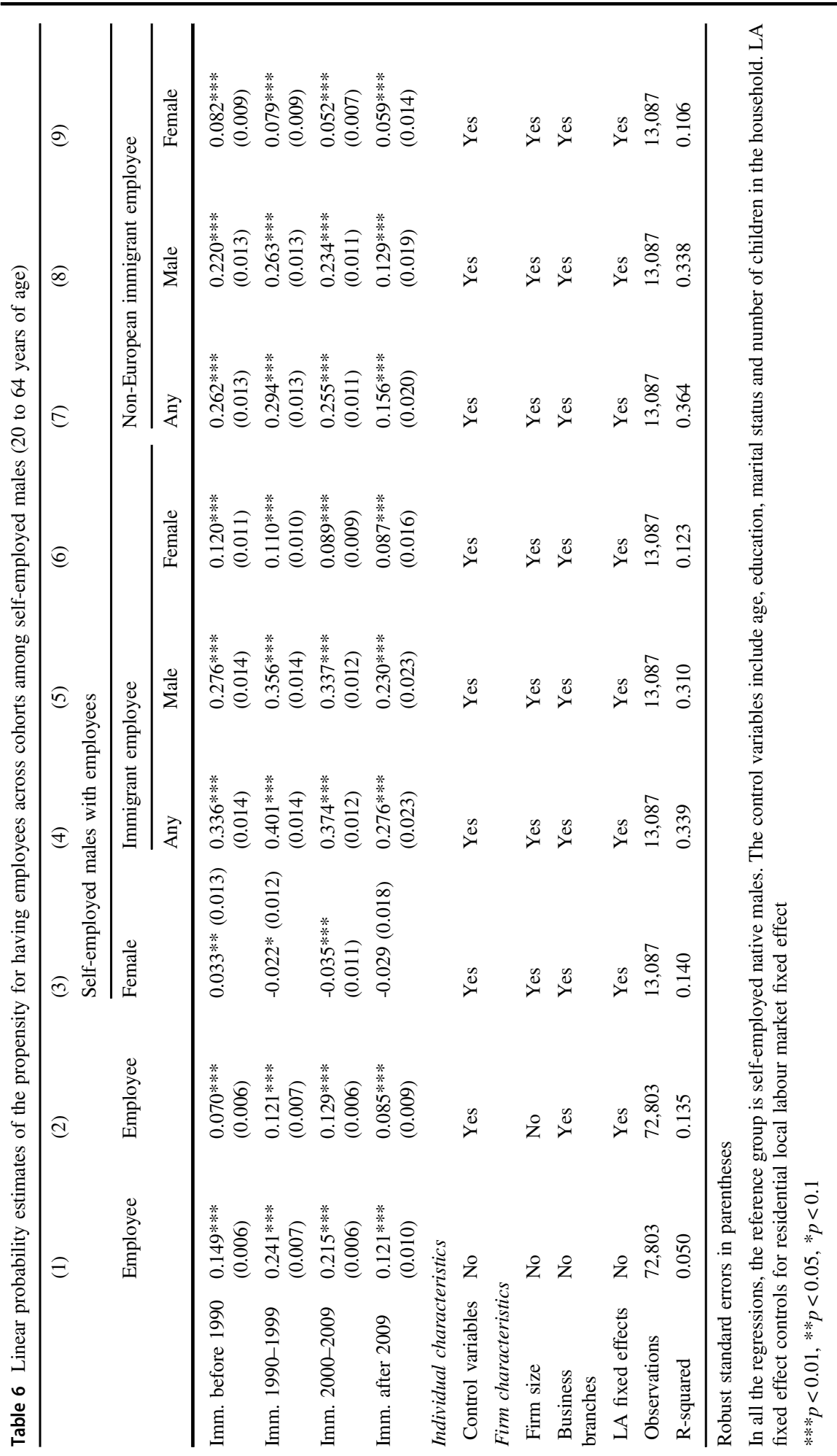




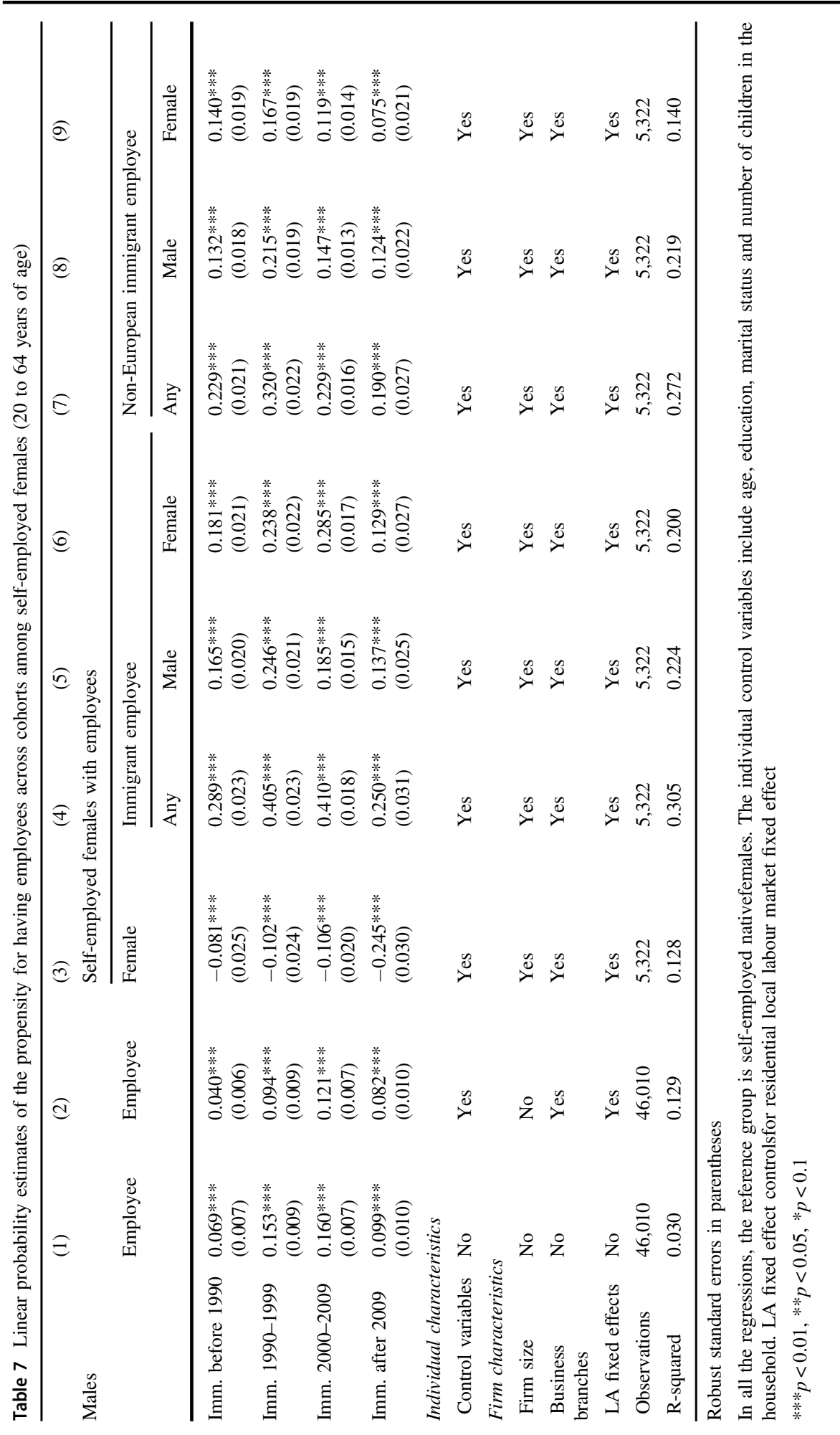


and 5, with a focus on different immigrant cohorts. In Table 6 we find that selfemployed male immigrants are more likely to have employees independently of the time of their arrival. Male immigrants who arrived between 1990 and 1999 or between 2000 and 2009 are the most likely groups to have employees. For those cohorts, the difference compared to natives amounts to around 12 percentage points when we control for different background characteristics.

Furthermore, all cohorts of male self-employed immigrants are also more likely than natives to have immigrants and non-European immigrants as employees. In fact, the differences among the various cohorts are relatively small in this respect.

The results also show that all cohorts of self-employed females are more likely to have employees than self-employed native females are. These results are presented in Table 7. All cohorts of self-employed immigrant females are less likely to have female employees than native females are. The largest difference compared to selfemployed native females is found for the cohort that arrived after 2009. The propensity for having a female employee is 24 percentage points lower in this cohort than it is for native females.

Finally, all cohorts of self-employed female immigrants are more likely to have immigrants and non-European immigrants as employees than natives are. Just as for males, the differences between the various cohorts are relatively small in this respect. Thus, we can conclude that the pattern established in the previous section is not driven by the fact that different groups of immigrants have different times of arrival in Sweden. Irrespective of the time at which they arrived, self-employed immigrants are more likely than natives to have employees and non-European immigrants as employees in their firms. ${ }^{17}$

\subsection{The propensity for hiring recently arrived non-European immigrants}

In this section we focus on the extent to which self-employed immigrants have recently employed non-European immigrants in their firms. It is well documented that especially low educated, recently arrived immigrants from non-European countries suffer from difficulties on the Swedish labour market. ${ }^{18}$ Table 8 reveals that the propensity for having at least one recently arrived non-European immigrant as an employee is more than 20 percentage points higher for self-employed men originating from the Middle East, other Asian countries or Africa, than it is for selfemployed native males. ${ }^{19}$ The differences between these groups and natives are statistically significant when we focus on the propensity for having at least one recently arrived non-European immigrant with a low education as an employee.

A similar pattern occurs when we focus on self-employed females. Self-employed immigrant females originating from the Middle East, Africa or Latin America have approximately a 25 percentage point higher propensity for having at least one recently arrived non-European immigrant employee than self-employed native

\footnotetext{
17 The full set of estimates is presented in Table 13 and Table 14 in the Appendix.

18 See Aldén and Hammarstedt (2015).

19 The full estimates are presented in Table 15 in the Appendix.
} 
Table 8 Linear probability estimates of hiring recently arrived immigrants among self-employed individuals (20 to 64 years of age)

\begin{tabular}{|c|c|c|c|c|}
\hline & (1) & (2) & (3) & (4) \\
\hline & \multicolumn{2}{|c|}{ Self-employed males } & \multicolumn{2}{|c|}{ Self-employed females } \\
\hline & $\begin{array}{l}\text { Recently arrived } \\
\text { non-European } \\
\text { immigrants }\end{array}$ & $\begin{array}{l}\text { Recently arrived non-European } \\
\text { immigrants with nine years of } \\
\text { compulsory school or less }\end{array}$ & $\begin{array}{l}\text { Recently arrived } \\
\text { non-European } \\
\text { immigrants }\end{array}$ & $\begin{array}{l}\text { Recently arrived non-European } \\
\text { immigrants with nine years of } \\
\text { compulsory school or less }\end{array}$ \\
\hline $\begin{array}{l}\text { Nordic } \\
\text { countries }\end{array}$ & $0.016(0.013)$ & $-0.001(0.006)$ & $0.047 *(0.025)$ & $0.035^{*}(0.019)$ \\
\hline $\begin{array}{l}\text { Western } \\
\text { Europe }\end{array}$ & $0.002(0.016)$ & $-0.003(0.009)$ & $0.028(0.023)$ & $0.025(0.019)$ \\
\hline $\begin{array}{l}\text { Eastern } \\
\text { Europe }\end{array}$ & $\begin{array}{l}-0.014 * * \\
(0.007)\end{array}$ & $0.002(0.005)$ & $-0.009(0.009)$ & $0.005(0.006)$ \\
\hline $\begin{array}{l}\text { Southern } \\
\text { Europe }\end{array}$ & $0.011(0.010)$ & $0.003(0.007)$ & $0.007(0.018)$ & $-0.001(0.010)$ \\
\hline Middle East & $0.221 * * *(0.009)$ & $0.113 * * *(0.007)$ & $0.246^{* * *}(0.020)$ & $0.114 * * *(0.015)$ \\
\hline Asia & $0.253 * * *(0.023)$ & $0.090 * * *(0.017)$ & $0.320 * * *(0.021)$ & $0.132 * * *(0.015)$ \\
\hline Africa & $0.221 * * *(0.025)$ & $0.072 * * *(0.016)$ & $0.227 * * *(0.049)$ & $0.132 * * *(0.039)$ \\
\hline Latin America & $0.167 * * *(0.034)$ & $0.024(0.015)$ & $0.246^{* * *}(0.048)$ & $0.065^{* *}(0.029)$ \\
\hline \multicolumn{5}{|c|}{ Individual characteristics } \\
\hline $\begin{array}{c}\text { Control } \\
\text { variables }\end{array}$ & Yes & Yes & Yes & Yes \\
\hline \multicolumn{5}{|c|}{ Firm characteristics } \\
\hline Firm size & Yes & Yes & Yes & Yes \\
\hline $\begin{array}{l}\text { Business } \\
\text { branches }\end{array}$ & Yes & Yes & Yes & Yes \\
\hline $\begin{array}{l}\text { LA fixed } \\
\text { effects }\end{array}$ & Yes & Yes & Yes & Yes \\
\hline Observations & 13,087 & 13,087 & 5,322 & 5,322 \\
\hline R-squared & 0.257 & 0.136 & 0.244 & 0.117 \\
\hline
\end{tabular}

Robust standard errors in parentheses

In all the regressions, the reference group is self-employed natives with employees. The control variables include age, education, marital status and number of children in the household. LA fixed effect controls for residential local labour market fixed effect

$* * * p<0.01, * * p<0.05, * p<0.1$

females. For self-employed females originating from other Asian countries than those in the Middle East the difference compared to natives is over 30 percentage points.

Finally, self-employed non-European females are also more likely than selfemployed female natives to have recently arrived non-Europeans with low education as employees in their firms.

\section{Conclusions}

We have presented a study of the employees of self-employed immigrants in Sweden. Our study is limited to unincorporated firms. The study provides new insights on the role immigrant self-employment plays in the integration process. It is often argued that self-employment among immigrants is a way of escaping unemployment, and that self-employed immigrants can create employment opportunities for other immigrants. 
Our study provides us with important insights regarding the recruitment behaviour of immigrant firms. We find that self-employed immigrants are more likely than selfemployed natives to have employees. Furthermore, self-employed immigrants are more likely than natives to hire immigrants as employees. ${ }^{20}$ This is especially true for self-employed immigrants from non-European countries. Self-employed males are more likely to have employees than self-employed females, but self-employed females are more likely than self-employed males to have female employees. This is the case for all groups of immigrants as well as for natives.

In studying non-European immigrants, one result of particular interest emerges. Self-employed immigrants originating from non-European countries are more likely to have non-European immigrants as employees in their firms than natives and European immigrants are. Furthermore, self-employed non-European immigrants are also more likely than others to have recently arrived non-European immigrants with low education as employees in their firms. ${ }^{21}$

The policy relevance of our results is obvious. The integration problems of recently arrived non-European immigrants on the Swedish labour market are well documented. ${ }^{22}$ How to improve the labour market situation for these immigrants has been a subject of debate in Sweden and other European countries during the past decades. Our results underline that immigrant self-employment may play an important role in the integration process since self-employed immigrants also create employment opportunities for groups that have difficulties entering the labour market.

To what extent do the results in our study provide us with new insights compared to what has been found in previous research from other countries? As stated in the introduction, research from countries such as the United States and the United Kingdom has paid attention to immigrant self-employment and to the employees of self-employed immigrants. Our study adds knowledge to this research area by highlighting the gender dimension when studying the employees of self-employed immigrants. Furthermore, we focus on other new dimensions, such as the educational attainment among the employees of self-employed immigrants.

Finally, it is clear that knowledge regarding the explanations behind the results in our study is still limited. More research in this area is needed, not least to improve our understanding of the mechanisms behind immigrants' decision to have employees in their firms. More research is required to establish who is employed by self-employed immigrants, and how the employees of self-employed immigrants perform in the labour market in the long run.

Open Access This article is distributed under the terms of the Creative Commons Attribution 4.0 International License (http://creativecommons.org/licenses/by/4.0/), which permits use, duplication, adaptation, distribution, and reproduction in any medium or format, as long as you give appropriate credit to the original author(s) and the source, provide a link to the Creative Commons license, and indicate if changes were made.

\footnotetext{
${ }^{20}$ This is in line with the result in Andersson and Wadensjö (2009).

21 This result is in line with Giuliano et al. (2009) and Åslund et al. (2014).

22 Different studies have shown that non-European immigrants are discriminated against in Sweden, see e.g., Carlsson and Rooth (2007) and Ahmed and Hammarstedt (2008).
} 


\section{Appendix}

Tables 9-15

Table 9 Countries included in the different regions

\begin{tabular}{|c|c|}
\hline Region & Countries included \\
\hline Nordic countries & Finland, Norway, Denmark, Iceland \\
\hline Western Europe & $\begin{array}{l}\text { Belgium, France, Ireland, Luxemburg, the Netherlands, United Kingdom, Germany, } \\
\text { Austria, Switzerland, Israel, United States, Canada, Oceania }\end{array}$ \\
\hline Eastern Europe & $\begin{array}{l}\text { Poland, Slovakia, the Czech Republic, Czechoslovakia, DDR, Hungary, Bulgaria, } \\
\text { Romania, Russia, Ukraine, Belarus, Estonia, Latvia, Lithuania, the Soviet Union }\end{array}$ \\
\hline Southern Europe & $\begin{array}{l}\text { Greece, Italy, Portugal, Spain, Albania, Bosnia-Hercegovina, Gibraltar, Yugoslavia, } \\
\text { Croatia, Macedonia, Moldavia, Serbia, Montenegro, Cyprus, Malta, Slovenia }\end{array}$ \\
\hline The Middle East & $\begin{array}{l}\text { Turkey, the United Arab Emirates, Bahrain, Iraq, Iran, Jordan, Kuwait, Lebanon, } \\
\text { Oman, Pakistan, Palestine, Qatar, Saudi Arabia, Syria, Yemen }\end{array}$ \\
\hline Asia & Asian countries except the Middle East \\
\hline Africa & African countries \\
\hline Latin America & Latin American countries \\
\hline
\end{tabular}

Table 10 List of variables

\section{Outcome variables}

Self-employed with employee

Self-employed with at least one female employee

Self-employed with at least one immigrant employee

Self-employed with at least one male immigrant employee

Self-employed with at least one female immigrant employee

Self-employed with at least one non-European immigrant employee

Self-employed with at least one non-European male immigrant employee

Self-employed with at least one non-European female immigrant employee

Self-employed with at least one recently arrived non-European immigrant employee

Self-employed with at least one recently arrived non-European immigrant employee with nine years of compulsory school or less
Dummy variable: 1 if self-employed with at least one employee, 0 if self-employed without any employee.

Dummy variable: given self-employment with employee, 1 if self-employed with at least one female employee, otherwise 0 .

Dummy variable: given self-employment with employee, 1 if self-employed with at least one immigrant employee, otherwise 0 .

Dummy variable: given self-employment with employee, 1 if self-employed with at least one male immigrant employee, otherwise 0 .

Dummy variable: given self-employment with employee, 1 if self-employed with at least one female immigrant employee, otherwise 0 .

Dummy variable: given self-employment with employee, 1 if self-employed with at least one non-European immigrant employee, otherwise 0 .

Dummy variable: given self-employment with employee, 1 if self-employed with at least one non-European male immigrant employee, otherwise 0 .

Dummy variable: given self-employment with employee, 1 if self-employed with at least one non-European female immigrant employee, otherwise 0 .

Dummy variable: given self-employment with employee, 1 if self-employed with at least one immigrant employee who arrived after 2009, otherwise 0 .

Dummy variable: given self-employment with employee, 1 if self-employed with at least one immigrant employee with nine years of compulsory schooling who arrived after 2009 , otherwise 0 . 
Table 10 continued

Outcome variables

Explanatory variables

Nordic countries

Western Europe

Eastern Europe

Southern Europe

Middle East

Asia

Africa

Latin America

Immigrated before 1990

Immigrated 1990-1999

Immigrated 2000-2009

Immigrated after 2009

Age

Marriage

Nine years of compulsory school or less

Upper secondary school

University

Children in the household

Firm size

Local labour market dummies

Business branches
Dummy variable: 1 if born in Nordic countries, excluding Sweden, otherwise 0 .

Dummy variable: 1 if born in Western European countries, Northern America and Oceania, otherwise 0.

Dummy variable: 1 if born in Eastern European countries, otherwise 0 .

Dummy variable: 1 if born in Southern European countries, otherwise 0

Dummy variable: 1 if born in Middle Eastern countries, otherwise 0

Dummy variable: 1 if born in Asian countries, otherwise 0 .

Dummy variable: 1 if born in African countries, otherwise 0 .

Dummy variable: 1 if born in Latin American countries, otherwise 0 .

Dummy variable: 1 if immigrants arrived before 1990, 0 otherwise.

Dummy variable: 1 if immigrants arrived between 1990 and 1999, 0 otherwise.

Dummy variable: 1 if immigrants arrived between 2000 and 2009, 0 otherwise.

Dummy variable: 1 if immigrants arrived after 2009, 0 otherwise.

Continuous variable: age in 2014.

Dummy variable: 1 if married, otherwise 0 .

Dummy variable: 1 if nine years of compulsory schooling or less, otherwise 0 .

Dummy variable: 1 if upper secondary school, otherwise 0 .

Dummy variable: 1 if university educated, otherwise 0 .

Continuous variable: the number of children in the household.

Continuous variable: the number of employees in the firm.

Dummy variables for each residential local labour market. The classification is based on the Statistics Sweden 2014 classification, with a total of 73 local labour markets.

A business branch is classified as manufacturing/construction, sales/retail trade, transportation/ warehouse, hotel/restaurant, personal services, business services, healthcare/social work, and others. 


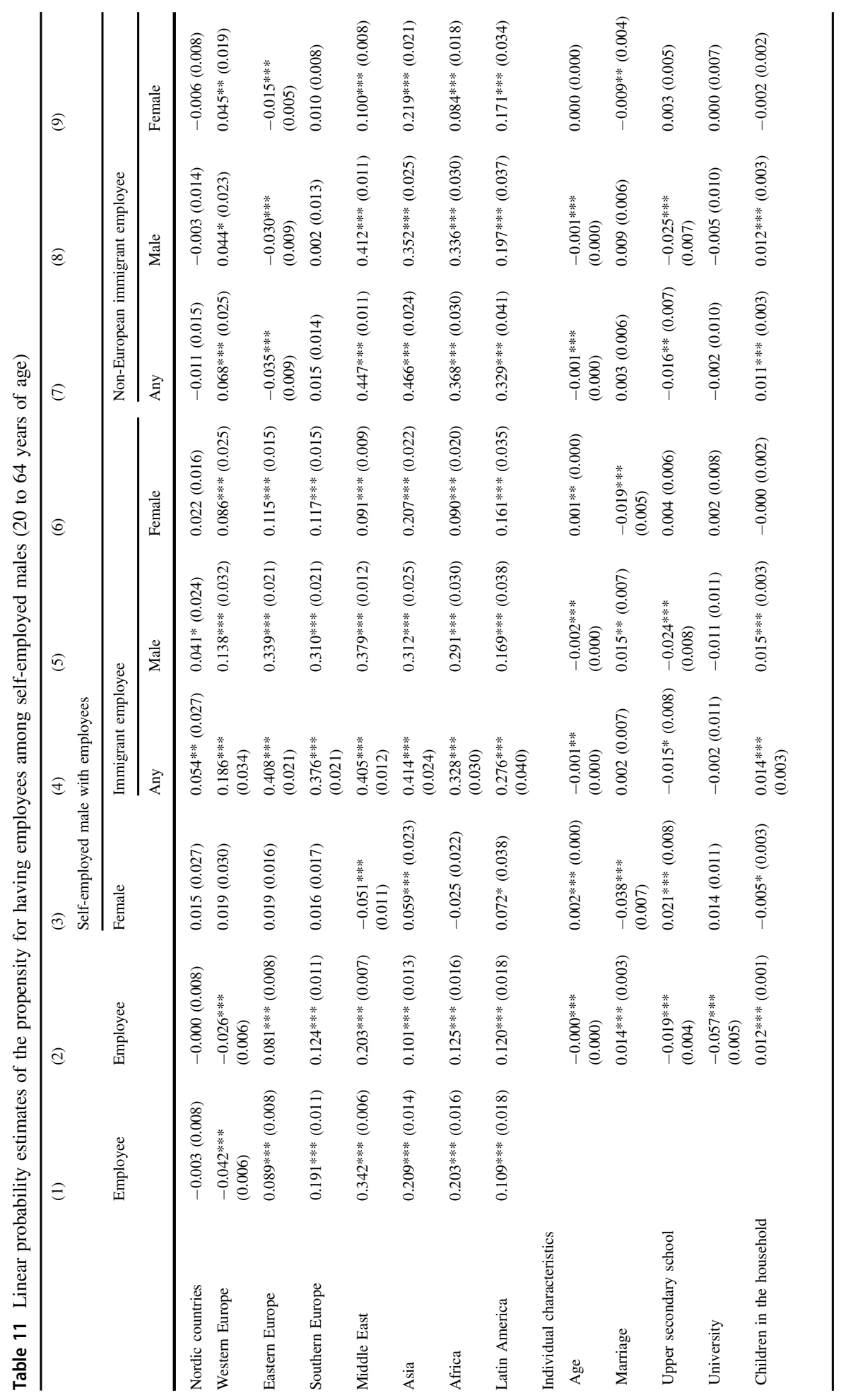




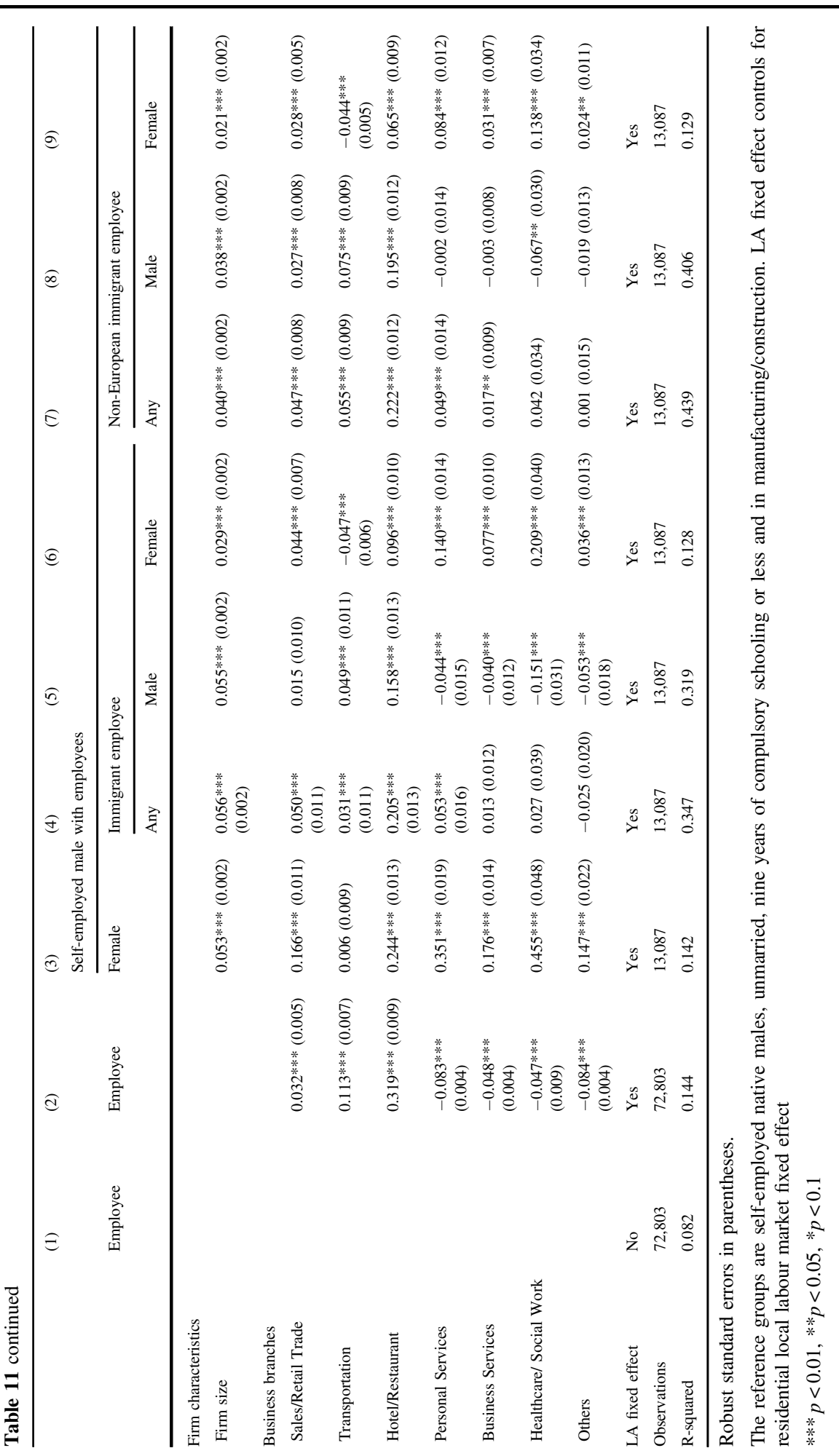




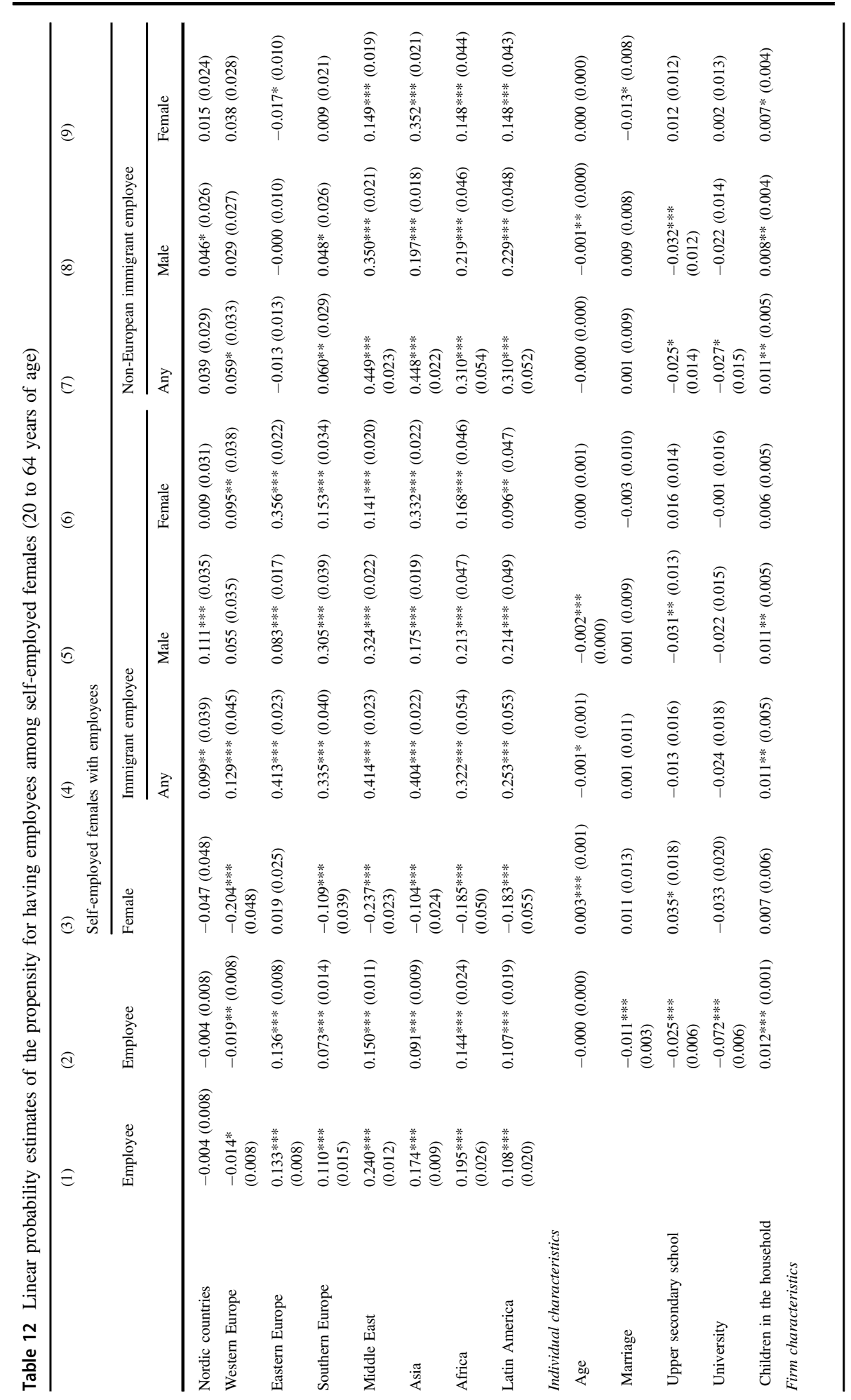




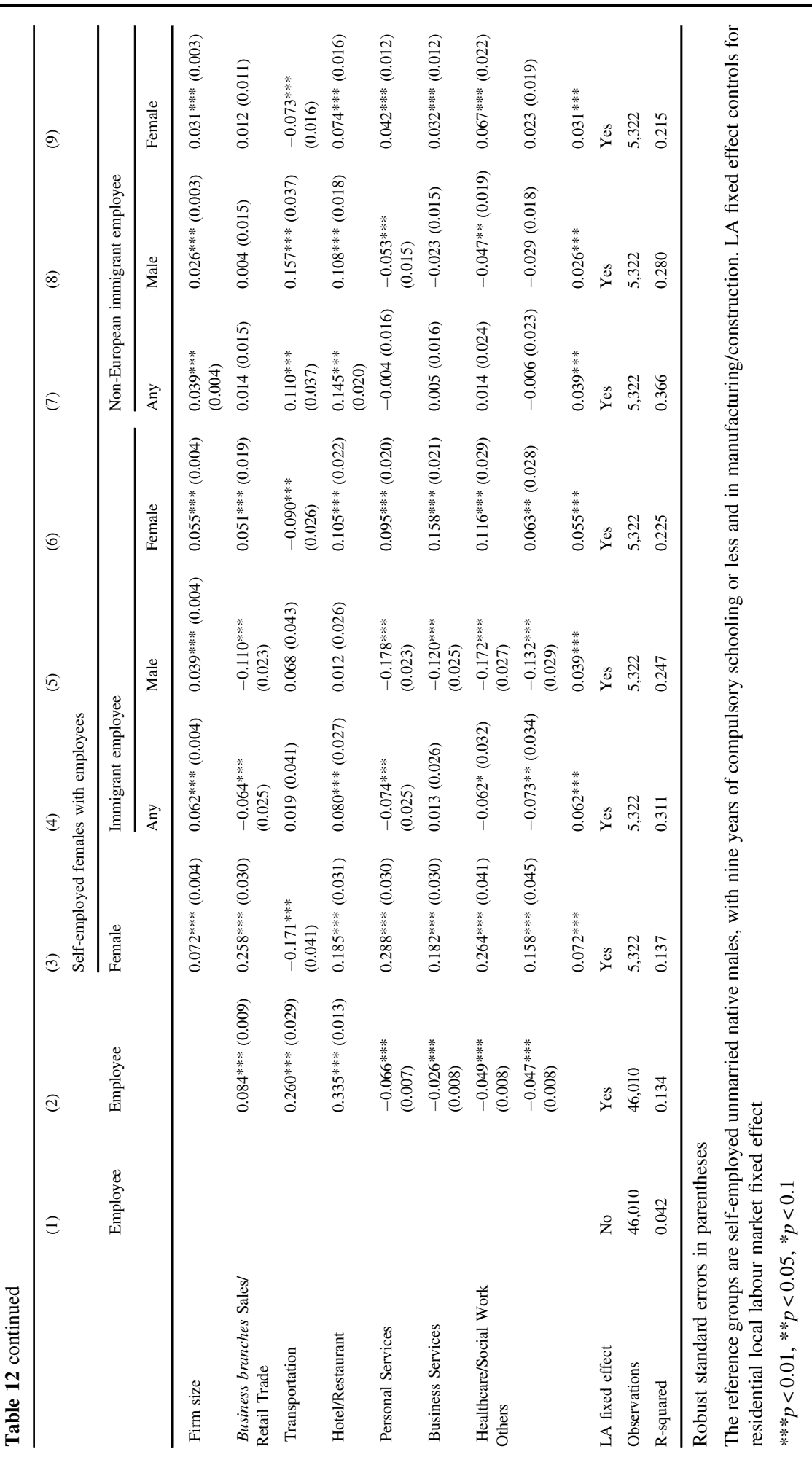




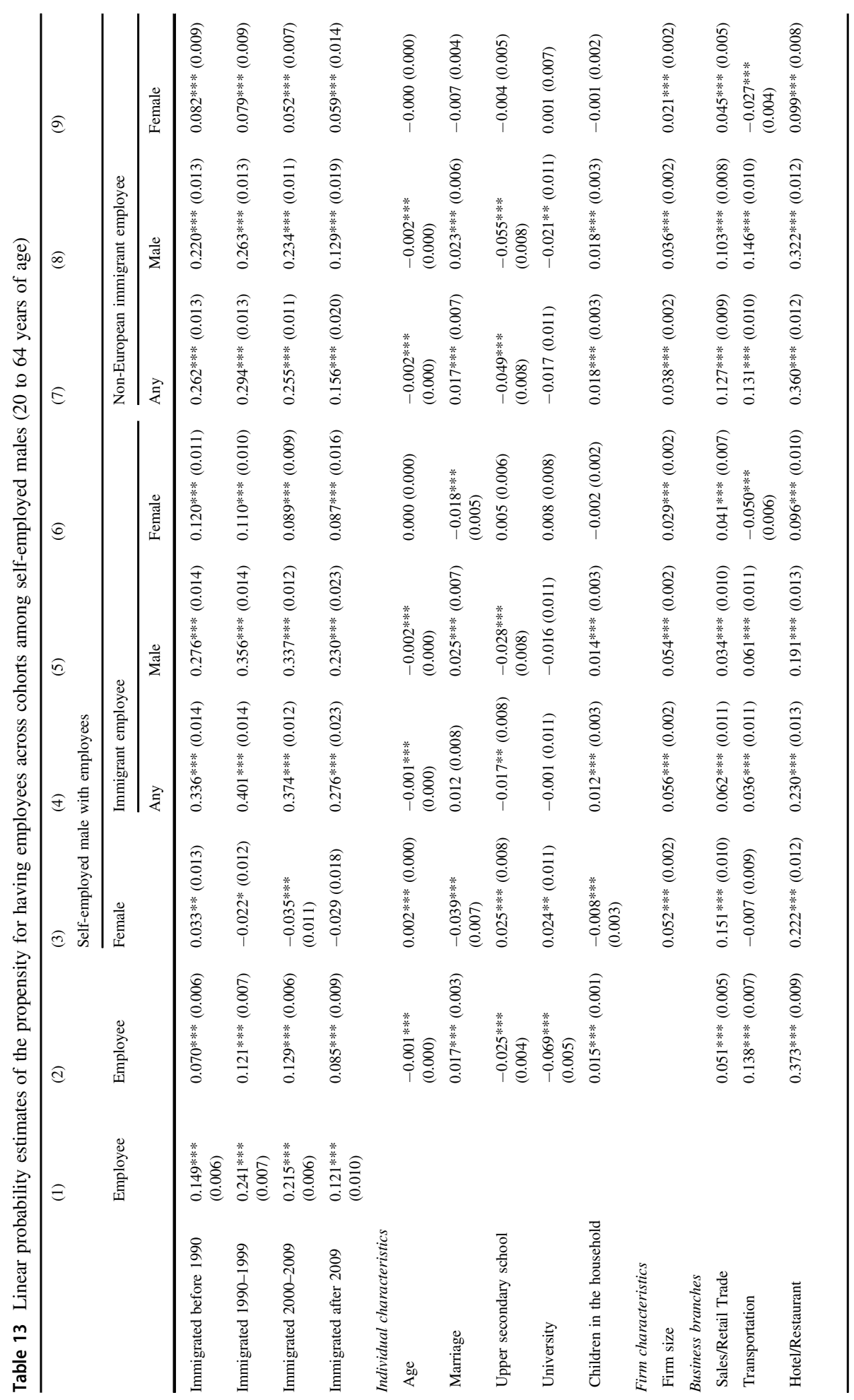




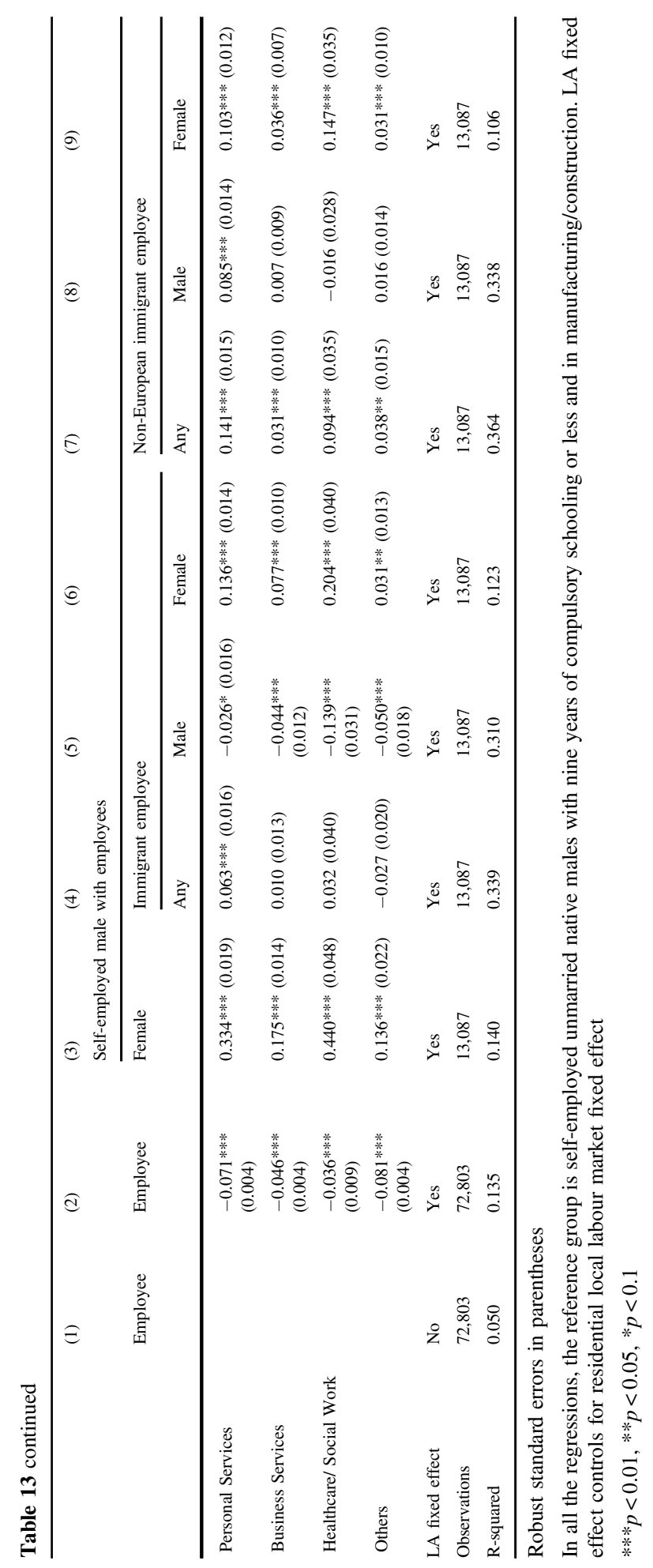




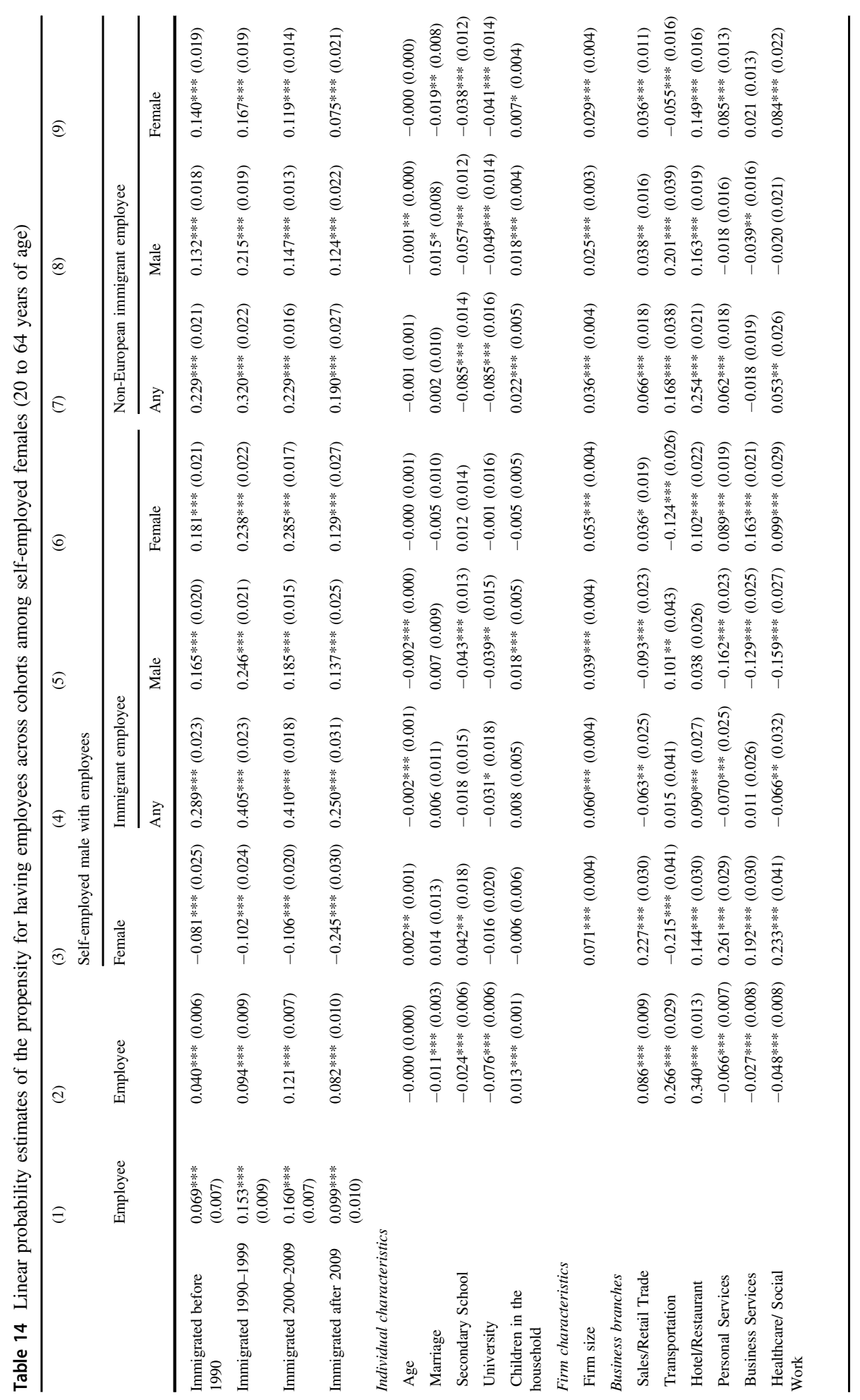




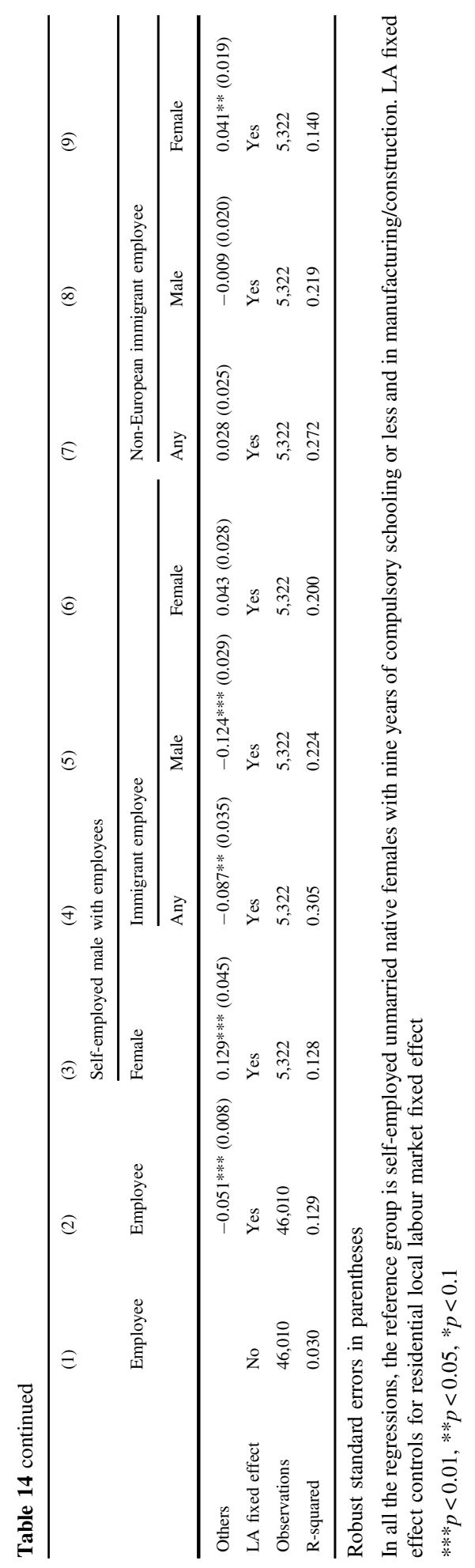

슬 Springer 


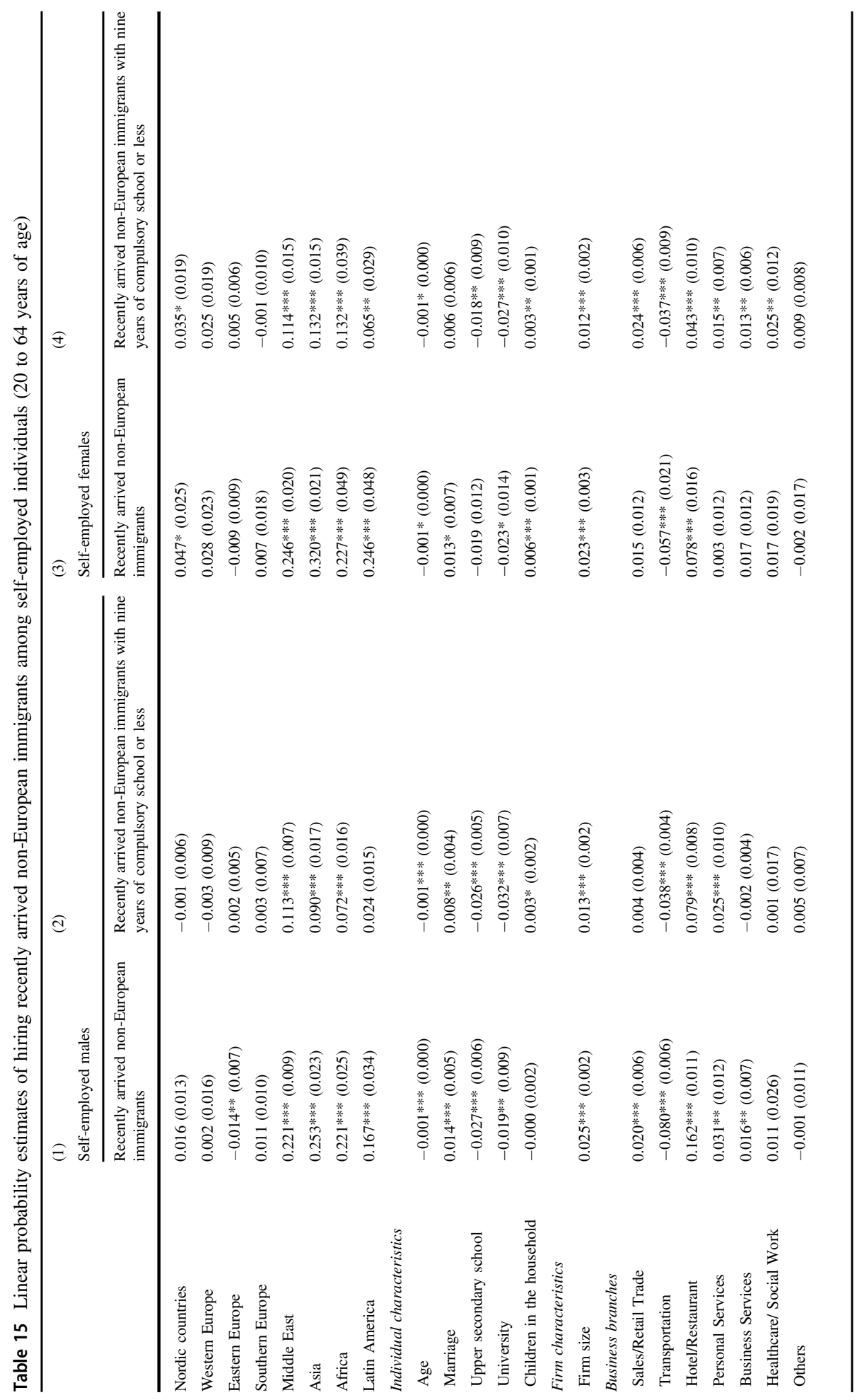




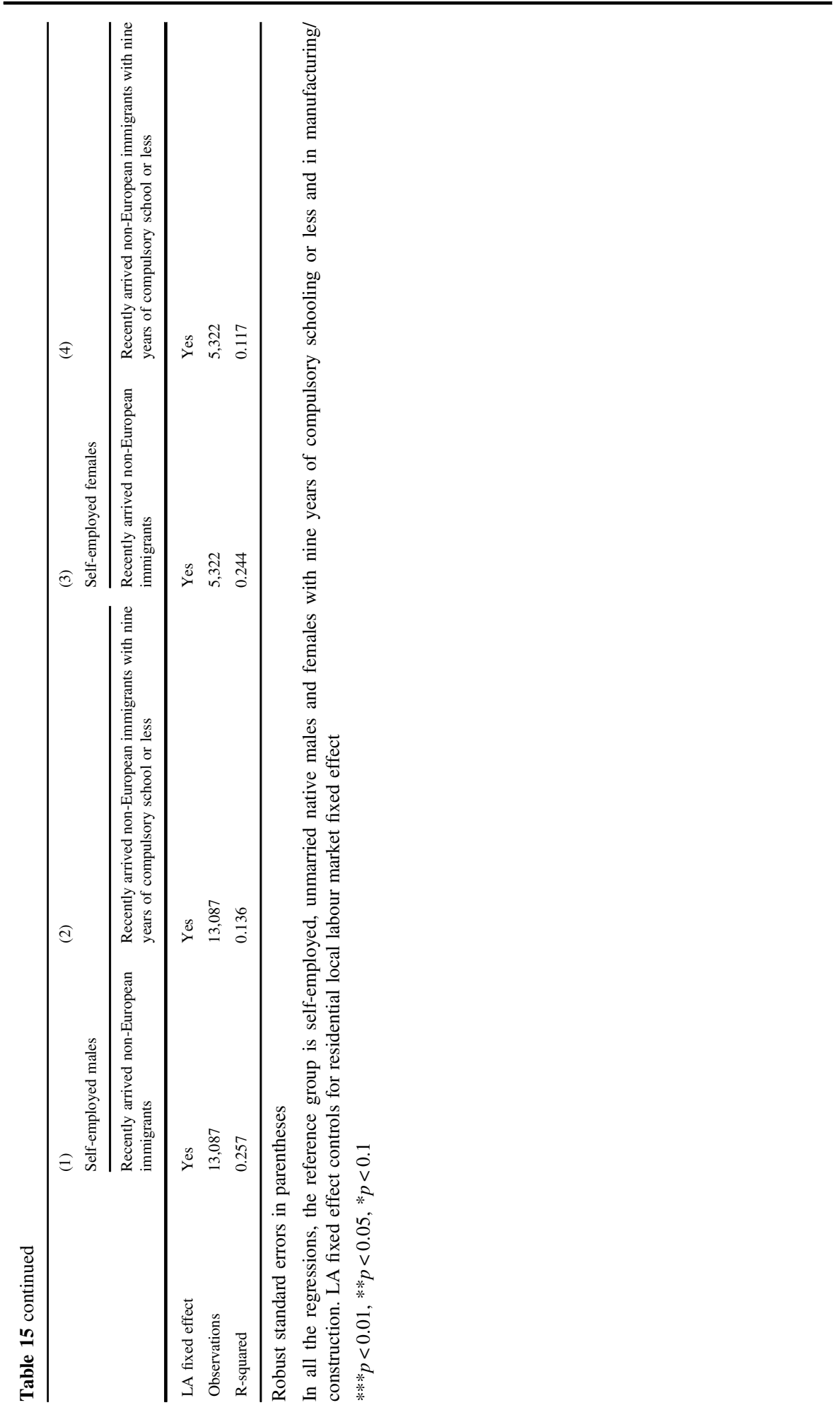

\footnotetext{
를 Springer
} 


\section{References}

Ahmed, A., \& Hammarstedt, M. (2008). Discrimination in the rental housing market - a field experiment on the internet. Journal of Urban Economics, 64(2), 362-372.

Aldén, L., \& Hammarstedt, M. (2015). Utrikes födda på 2000-talets arbetsmarknad - En översikt och förklaringar till situationen. Ekonomisk Debatt, 43(3), 77-89.

Aldén, L., \& Hammarstedt, M. (2016). Discrimination in the credit market? Access to financial capital among self-employed immigrants. Kyklos, 69(1), 3-31.

Aldén, L. \& Hammarstedt, M. (2017). Egenföretagande bland utrikes födda. En översikt av utvecklingen under 2000-talet. Arbetsmarknadsekonomiska rådet - Underlagsrapport, 1/2017.

Andersson, L., \& Hammarstedt, M. (2010). Intergenerational transmissions in immigrant self-employment: Evidence from three generations. Small Business Economics, 34(3), 261-276.

Andersson, L., \& Hammarstedt, M. (2011). Transmission of self-employment across immigrant generations: The importance of ethnic background and gender. Review of Economics of the Household, 9(4), 555-577.

Andersson, L., \& Hammarstedt, M. (2015). Ethnic enclaves, networks and self-employment among Middle Eastern immigrants in Sweden. International Migration, 53(6), 27-40.

Andersson, P., \& Wadensjö, E. (2009). The employees of native and immigrant self-employed. Research in Labor Economics, 29, 229-250.

Andersson-Joona, P., \& Wadensjö, E. (2012). Being employed by a co-national: A cul-de-sac or a short cut to the main road of the labour market? Journal of Integration and Migration Studies, 13(1), 99-120.

Åslund, O., Hensvik, L., \& Nordström Skans, O. (2014). Seeking similarity: How immigrants and natives manage in the labor market. Journal of Labor Economics, 32(3), 405-441.

Bandiera, O., Barankay, I., \& Rasul, I. (2009). Social connections and incentives in the workplace: Evidence from personnel data. Econometrica, 77(4), 1047-1094.

Becker, G. S. (1957). The economics of discrimination. Chicago: Chicago University Press.

Boguslaw, J. (2012). Svensk Invandringspolitik Under 500 år: 1512-2012. Lund: Studentlitteratur.

Borjas, G. J. (1986). The self-employment experience of immigrants. Journal of Human Resources, 21(4), 487-506.

Carlsson, M., \& Rooth, D.-O. (2007). Evidence of ethnic discrimination in the Swedish labor market using experimental data. Labour Economics, 14(4), 16-29.

Clark, K., \& Drinkwater, S. (2000). Pushed out or pulled in? Self-employment among ethnic minorities in England and Wales. Labour Economics, 7(5), 603-628.

Clark, K., \& Drinkwater, S. (2002). Ethnic enclaves, neighbourhood effects and employment outcomes: Ethnic minorities in England and Wales. Journal of Population Economics, 15(1), 5-29.

Clark, K., Drinkwater, S., \& Robinson, C. (2017). Self-employment among migrant groups: New evidence from England and Wales. Small Business Economics, 48(4), 1047-1069.

Constant, A., \& Zimmermann, K. F. (2006). The making of entrepreneurs in Germany: Are immigrants and natives alike? Small Business Economics, 26(3), 279-300.

Den Butter, F.A.G., Masurell, E. \& Mosch, R.H.J. (2004). The economics of co-ethnic employment. Discussion Paper, 2004-027/3, Tinbergen, Tinbergen Institute.

Fairlie, R. W. (1999). The absence of the African-American owned businesses: An analysis of the dynamics of self-employment. Journal of Labor Economics, 17(1), 80-108.

Fairlie, R. W., \& Meyer, B. D. (1996). Ethnic and racial self-employment differences and possible explanations. Journal of Human Resources, 31(4), 757-793.

Fairlie, R. W., \& Miranda, J. (2017). Taking the leap: The determinants of entrepreneurs hiring their first employee. Journal of Economics \& Management Strategy, 26(1), 334.

Fairlie, R. W., \& Robb, A. M. (2007). Why are black-owned businesses less successful than white-owned businesses? The role of families, inheritances, and business human capital. Journal of Labor Economics, 25(2), 289-323.

Giuliano, L., Levine, D. I., \& Leonard, J. (2009). Manager race and the race of new hires. Journal of Labor Economics, 27(4), 589-631.

Hammarstedt, M. (2001). Immigrant self-employment in Sweden - Its variation and some possible determinants. Entrepreneurship and Regional Development, 13(2), 147-161.

Hammarstedt, M. (2004). Self-employment among immigrants in Sweden - An analysis of intragroup differences. Small Business Economics, 23(2), 115-126.

Hammarstedt, M. (2006). The predicted earnings differential and immigrant self-employment in Sweden. Applied Economics, 38(6), 619-630. 
Hammarstedt, M., \& Shukur, G. (2009). Testing the home-country self-employment hypothesis on immigrants in Sweden. Applied Economics Letters, 16(7), 745-748.

Henley, A. (2005). Job creation by the self-employed: The roles of entrepreneurial and financial capital. Small Business Economics, 25(2), 175-196.

Hout, M., \& Rosen, H. (2000). Self-employment, family background, and race. Journal of Human Resources, 35(4), 670-691.

Lazear, E. P. (1999). Culture and language. Journal of Political Economy, 107(56), 95-126.

Le, A. T. (2000). The determinants of immigrant self-employment in Australia. International Migration Review, 34(1), 183-214.

Robb, A. M., \& Fairlie, R. W. (2009). Determinants of business success: An examination of Asian-owned businesses in the USA. Journal of Population Economics, 22(4), 253-266.

Yuengert, A. M. (1995). Testing hypotheses of immigrant self-employment. Journal of Human Resources, 30(1), 194-204. 